Ricci Rahmatillah, Jr. ${ }^{1}$ Amir Luthfi ${ }^{2}$

Moh Fauziddin ${ }^{3}$

\section{Pengaruh Metode Bercerita terhadap Kemampuan Menyimak pada Anak Usia Dini}

\begin{abstract}
ABSTRAK
Penelitian ini bertujuan untuk mengetahui pengaruh metode bercerita terhadap kemampuan menyimak pada anak usia 5-6 tahun di TK Mutiara Kampung Godang. Tujuan dari penelitian ini adalah untuk menguji hipotesis metode bercerita terhadap kemampuan menyimak anak. Metode penelitian ini adalah pre-eksperimental design dengan jenis One-Group Pre-test Post-test Design. Sampel penelitian ini adalah 15 anak (7 anak laki-laki dan 8 anak perempuan). Teknik pengumpulan data yang digunakan adalah observasi dan dokumentasi. Teknik analisa data menggunakan statistik dengan uji t-test dengan program SPPS 16.0. Pengujian hipotesis dilakukan dengan menggunakan uji-t dengan teknik Independent T-test, diperoleh thitung sebesar 0,000 pada taraf signifikansi $\alpha<0.050$. Dengan demikian $\mathrm{H}_{0}$ ditolak dan $\mathrm{H}_{\mathrm{a}}$ diterima karena $0.000<0.05$. Hal ini membuktikan bahwa metode bercerita berpengaruh terhadap kemampuan menyimak anak.
\end{abstract}

Kata kunci : Kemampuan Menyimak, Metode Bercerita

\title{
ABSTRACT
}

This research is intended to know the influence of storytelling method on the listening skills of children aged 5-6 years in TK Mutiara Kampung Godang. The purpose of the study was to test the hypothesis of storytelling method to the listening skills of children. The method of this research is a Pre-experimental Design with One-Group Pre-Test PostTest Design. The sample of this research is 20 children ( 7 son and 8 daughter). The data collection techniques used consisted of observation and documentation. The technique of data analysis uses statistic with t-test with programs SPSS 16.0. Hypothesis is testing is done by using t-tes with technique Independent T-test, obtained thitung 0,000 at significance level $\alpha<0.050$. thus $\mathrm{H}_{0}$ rejected and $\mathrm{H}_{\mathrm{a}}$ accepted because of $0.000<0.05$. this proves that the storytelling method affects the listening skill of children.

Keyword : Listening Skill, Storytelling Method

\footnotetext{
${ }^{1}$ Prodi PG-PAUD Universitas Pahlawan Tuanku Tambusai, Riau, Indonesia

Email : riccirahmatillah@gmail.com

2 Universitas Pahlawan Tuanku Tambusai

${ }^{3}$ Prodi PG-PAUD Universitas Pahlawan Tuanku Tambusai, Riau, Indonesia
} 


\section{PENDAHULUAN}

Anak usia dini adalah anak yang berada pada rentang usia 0-8 tahun. Pada masa usia ini anak mengalami pertumbuhan dan perkembangan yang sangat pesat dalam berbagai aspek perkembangan, masa ini juga disebut masa keemasan (golden age) (Sujiono, 2009: 6). Ketika anak berada pada usia dini harus diberi stimulus dan pendidikan yang baik sehingga dapat merangsang perkembangan dan pertumbuhan anak secara optimal. Berdasarkan Peraturan Menteri Pendidikan dan Kebudayaan Republik Indonesia Nomor 146 Tahun 2014 bahwa : Pendidikan anak usia dini (PAUD) merupakan pendidikan yang paling fundamental karena perkembangan anak di masa selanjutnnya akan sangat ditentukan oleh berbagai stimulasi bermakna sejak usia dini. Awal kehidupan anak merupakan masa yang paling tepat dalam memberikan dorongan atau upaya pengembangan agar anak dapat berkembang secara optimal.

Dalam Undang-undang Nomor 20 Tahun 2003 Pasal 28 tentang sistem pendidikan nasional disebutkan bahwa "pendidikan anak usia dini merupakan jenjang pendidikan yang diselenggarakan sebelum pendidikan dasar, baik melalui pendidikan formal (TK, $\mathrm{RA}$ ), nonformal (KB, TPA) dan pendidikan informal berbentuk pendidikan keluarga atau pendidikan yang diselenggarakan di lingkungan tempat tinggalnya.

Pendidikan memang sangat penting bagi setiap orang, khususnya untuk anak karena anak adalah penerus bangsa yang seharusnya pendidikan bisa diberikan sejak dini dengan layak. Oleh karena itu, anak memerlukan program pendidikan yang mampu membuka kapasitas tersembunyi tersebut melalui pembelajaran bermakna seawal mungkin. Bila potensi pada diri anak dikembangkan, maka anak itu akan memperoleh peluang dan momentum penting dalam hidupnya. Untuk mengembangkan potensi pada diri anak bisa digunakan prinsip pembelajaran Anak Usia Dini yaitu prinsip "Belajar Sambil Bermain, Bermain Seraya Belajar" karena pada usia ini anak masih rentan dalam bermain maka dari itu prinsip inilah yang tepat digunakan untuk mengembangkan potensi pada diri anak.

Salah satu aspek perkembangan bahasa yang harus dikembangkan pada anak usia dini adalah kemampuan menyimak. Kemampuan menyimak merupakan bagian dari kemampuan bahasa yang sangat esensial, sebab kemampuan menyimak merupakan dasar untuk menguasai suatu bahasa. Menyimak adalah suatu proses kegiatan mendengarkan lambang-lambang lisan dengan penuh perhatian, pemahaman, apresiasi, serta interprestasi untuk memperoleh informasi, menangkap isi atau pesan serta memahami makna komunikasi yang telah disampaikan oleh sang pembicara melalui ujaran atau bahasa lisan" (Tarigan, 2008: 31). Sedangkan menurut Tarigan (2008: 60) mengemukakan tujuan utama menyimak adalah agar dia dapat memperoleh pengetahuan dari bahan ujaran sang pembicara dengan perkataan lain, dia menyimak untuk belajar.

Dalam Peraturan Menteri Pendidikan Nasional Nomor 137 Tahun 2014, tentang Standar Nasional PAUD pada perkembangan bahasa anak usia 4-5 tahun yaitu menyimak perkataan orang lain, mengerti dua perintah, dan memahami cerita yang dibacakan. Menurut Bromley dalam Dhieni (2007) ada dua alasan mengajari anak menyimak atau mendengarkan yaitu: 1. Anak dan orang dewasa sebagian besar menghabiskan waktunya untuk mendengar, 2. Kemampuan mendengarkan sangat penting tidak hanya belajar di dalam kelas tetapi juga dalam kehidupan sehari-hari. Misalnya mendengarkan pidato, berita, cerita, dan percakapan termasuk keahlian yang sering kita gunakan. 


\section{KAJIAN TEORI}

Metode bercerita merupakan cara atau media yang digunakan pendidik untuk menyampaikan atau menyajikan materi pembelajaran yang disampaikan secara lisan dalam bentuk cerita yang menarik kepada anak. Seperti yang telah dikemukakan oleh Moeslichatoen (2004: 157) bahwa "metode bercerita merupakan salah satu pemberian pengalaman belajar bagi anak TK, dengan membawakan cerita kepada anak secara lisan. Cerita yang dibawakan guru harus menarik, dan mengundang perhatian anak dan tidak lepas dari tujuan pendidikan bagi anak TK".

Bercerita adalah suatu kegiatan yang dilakukan seseorang secara lisan kepada orang lain dengan alat atau tanpa alat tentang apa yang harus disampaikan dalam bentuk pesan, informasi atau hanya sebuah dongeng yang untuk didengarkan dengan rasa menyenangkan, oleh karena itu orang yang menyajikkan cerita tersebut menyampaikannya dengan menarik (Dhieni, 2007: 6.4). Sedangkan menurut Gordon \&

Browne (dalam Isjoni, 2011) menyatakan bahwa bercerita merupakan cara untuk meneruskan warisan dari satu generasi berikutnya. Gunarti (2010: 5.3) menyatakan bahwa bercerita adalah "suatu kegiatan yang dilakukan seseorang untuk menyampaikan suatu pesan, informasi atau sebuah dongeng belaka yang bisa dilakukan secara lisan atau tertulis". Pendapat tersebut diperkuat oleh Dhieni (2007: 6.6) ia menjelaskan bahwa metode bercerita adalah cara penyampaian atau penyajian materi pembelajaran secara lisan dalam bentuk cerita dari guru kepada anak didik Taman Kanak-kanak. Dalam pelaksanaan kegiatan pembelajaran di PAUD metode bercerita dilaksanakan dalam upaya memperkenalkan, memberikan keterangan, atau penjelasan tentang hal baru dalam rangka menyampaikan pembelajaran yang dapat mengembangkan berbagai kompetensi dasar anak.

Bercerita mempunyai tujuan dimana pada dasarnya untuk menstimulus berbagai aspek perkembangan pada anak. Menurut Dhieni (2007: 6.7) tujuan bercerita bagi anak usia 4-6 tahun adalah agar anak mampu mendengarkan dengan seksama terrhadap apa yang disampaikan orang lain, anak dapat bertanya apabila tidak memahaminya, anak dapat menjawab pertanyaan, selanjutnya dapat melatih daya konsentrasi, mendengarkan, membangun pemahaman, mengungkapkan apa yang dipahaminya dan mengekspresikan terhadap apa yang didengarkan dan diceritakannya, sehingga hikmah dari isi cerita dapat dipahami dan lambat laun didengarkan, diperhatikan, dilaksanakan dan diceritakannya pada orang lain.

Pendapat tersebut diperkuat oleh Moeslichatoen (2004: 170) dalam kegiatan bercerita anak dibimbing mengembangkan kemampuan untuk mendengarkan cerita guru yang bertujuan untuk memberikan informasi atau menanamkan nilai-nilai sosial, moral, dan keagamaan, serta pemberian informasi tentang fisik dan lingkungan sosial. Di sisilain Isjoni (2011: 90) dengan pendapatnya bahwa metode bercerita dapat menjadi media untuk menyampaikan nila-nilai yang berlaku di masyarakat.

Menurut Fauziddin (2014: 20) cerita dapat berpengaruh pada pola pikir dan wawasan berpikir anak, terutama dalam mengembangkan aspek sosial-emosional anak. Secara umum, manfaat bercerita bagi anak sebagai berikut : mengembangkan sikap mental yang sesuai dengan ajaran agama Islam, memahami perbuatanyang terpuji dan yang tercela, menyiapkan anak dapat hidup sebagai makhluk sosial dalam masyarakat, mengembangkan kemampuan untuk berimajinasi logis dan sistematis, mengubah sikap anak untuk memahami diri sendiri dan lingkungannya, dan membentuk akhlak yang mulia sesuai dengan aqidah Islamiyah.

Berdasarkan pendapat di atas dapat disimpulkan manfaat metode bercerita adalah untuk melatih daya serap/ tangkap anak usia dini, untuk memberikan pengalaman belajar, 
untuk anak berlatih mendengarkan dan menyimak cerita yang dibawakan guru, untuk membantu perkembangan bahasa anak berkomunikasi secar aktif dan efesien. Karena melalui cerita anak dapat mengembangkan kemampuan berbahasanya dan memperoleh sejumlah pengetahuan sosial, nilai-nilai moral, dan keagamaan untuk dihayati dan diterapkam dalam kehidupan sehari-hari, serta mengembangkan daya pikir dan imajinasi akan lebih mudah sehingga dapat memperluas wawasan dan cara berfikir anak.

Metode bercerita digunakan dalam pembelajaran anak usia dini, khususnya dalam menyampaikan pesan-pesan dan nilai-nilai yang hendak diinternalisasikan kepada anak. Setiap metode pembelajaran pasti memiliki kelebihan dan kekurangan, untuk itu dengan adanya pembelajaran maka pengembangan metode yang bervariasi dapat membantu pencapaian tujuan setiap materi pembelajaran.

Menurut Dhieni (2007: 6.9) menyebutkan kelebihan metode bercerita antara lain: dapat menjangkau jumlah anak yang relative lebih banyak, waktu yang tersedia dapat dimanfaatkan dengan efektif dan efesian, pengaturan kelas menjadi lebih sederhana, guru dapat menguasai kelas dengan mudah, secara relatif tidak banyak memerlukan biaya, metode bercerita sangat efisien jika diterapkan untuk Anak Usia Dini, terlihat dari kelebihan metode bercerita yang dipaparkan di atas, metode bercerita merupakan salah satu metode yang tepat diberikan untuk anak usia dini. Selain memiliki kelebihan, metode bercerita juga memiliki kekurangan. Menurut Dhieni (2007: 6.9) kekurangan metode bercerita adalah: anak didik menjadi pasif, karena lebih banyak mendegarkan atau menerima penjelasan dari guru, kurang merangsang perkembangan kreativitas dan kemampuan anak untuk mengutarakan mendapatnya, daya tangkap atau serap anak didik berbeda dan masih lemah sehinnga sukar memahami tujuan pokok isi cerita, dan cepat menumbuhkan rasa bosan terutama apa bila penyajiannya tidak menarik.

Berdasarkan pendapat ahli di atas dapat disimpulkan bahwa kelebihan metode bercerita adalah melatih anak untuk berfantasi, belajar menyimak dan membaca apa yang diperagakan guru, dan belajar mengingat apa yang diceritakan oleh guru, sedangkan kekurangan metode bercerita adalah dalam mengekspresikan cerita guru kurang sehingga berpengaruh terhadap daya pikir dan fantasi anak, dan dalam memahami sebuah cerita anak merasa jenuh dan pasif.

\section{METODE PENELITIAN}

Metode dalam penelitian ini merupakan metode penelitian eksperimen (Experimental Research). Penelitian eksperimen adalah penelitian yang digunakan untuk mencari pengaruh perlakuan tertentu terhadap yang lain dalam kondisi yang terkendalikan. Kondisi yang terkendalikan di maksud adalah adanya hasil dari penelitian dikonversikan ke dalam angka-angka, untuk analisis yang digunakan dengan menggunakan analisis statistik (Sugiyono, 2014: 107).

Bentuk desain eksperimen yang digunakan dalam penelitian ini adalah PreExperimental Design. Menurut Sugiyono (2014: 109) bahwa pre-eksprimental design, desain ini belum merupakan eksperimen sungguh-sungguh karena masih terdapat variabel luar yang ikut berpengaruh terhadap terbentuknya variable dependen. Bentuk pre-experimental desain penelitian yang digunakan dalam penelitian ini adalah one group pretest-posttest design, yaitu desain penelitian yang terdapat pretest sebelum diberi perlakuan dan posttest setelah diberi perlakuan. Dengan demikian hasil perlakuan dapat diketahui lebih akurat, karena dapat membandingkan dengan keadaan sebelum diberi perlakuan (Sugiyono, 2014: 110). Dimana dalam desain penelitian ini hanya menggunakan satu kelompok subjek dan melakukan pengukuran sebelum dan sesudah perlakuan. Perbedaan hasil sebelum dan sesudah pemberian perlakuan pada subjek 
merupakan efek dari perlakuan, secara sistematis desain penelitian digambarkan pada tabel dibawah ini:

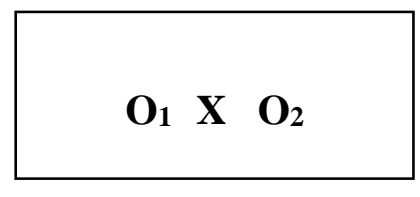

\section{Gambar 3.1 \\ Desain Penelitian}

Keterangan:

$\mathrm{O}_{1}=$ Nilai Pretest (kemampuan menyimak anak sebelum perlakuan)

$\mathrm{O}_{2} \quad=$ Nilai Posttest (kemampuan menyimak anak sesudah perlakuan)

$\mathrm{X}=$ Penerapan metode bercerita

$\left(\mathrm{O}_{2}-\mathrm{O}_{1}\right)=$ Pengaruh metode bercerita terhadap kemampuan menyimak anak

\section{HASIL DAN PEMBAHASAN}

Analisis data dilakukan dengan teknik ststistik t-test dengan bantuan SPSS 16.00. Teknik statistik t-test digunakan untuk menguji perbedaan sebelum dan sesudah perlakuan. Tujuan penelitian ini adalah untuk mengetahui pengaruh metode bercerita terhadap kemampuan menyimak pada anak usia 5-6 tahun di TK Mutiara Kampung Godang. Penelitian ini terdiri dua tes yaitu pretest dan posttest pada kelompok eksperimen yaitu anak usia 5-6 tahun yang terdiri dari 15 orang.

Kriteria pengambilan keputusan dalam pengujian hipotesis didasarkan pada nilai probalitas t statistik (sig.t) yang diperoleh berdasarkan taraf signifikansi $(\alpha)=0,05$. Bila nilai $\mathrm{p}<0,05$ berarti ada pengaruh dan signifikan. Gambaran tentang data penelitian secara umum disajikan pada tabel.

Tabel Deskripsi Hasil Penelitian

\begin{tabular}{|l|c|c|c|c|c|c|c|c|}
\hline \multirow{2}{*}{ Variabel } & \multicolumn{4}{|c|}{$\begin{array}{c}\text { Skor x dimungkinkan } \\
\text { (Hipotetik) }\end{array}$} & \multicolumn{4}{c|}{$\begin{array}{c}\text { Skor x yang diperoleh } \\
\text { (Empirik) }\end{array}$} \\
\cline { 2 - 9 } & Xmin & Xmax & Mean & SD & Xmin & Xmax & Mean & SD \\
\hline Pretest & 14 & 56 & 35 & 7 & 22 & 27 & 24,6 & 1,595 \\
\hline Posttest & 14 & 56 & 35 & 7 & 35 & 45 & 41,8 & 2,981 \\
\hline
\end{tabular}

Berdasarkan tabel diperoleh nilai rata-rata skor kemampuan menyimak anak meningkat setelah diberikan perlakuan (metode bercerita). Hal ini bisa dilihat pada nilai pretest kemampuan menyimak anak hanya mencapai $24.6 \%$. sedangkan pada nilai posttest setelah digunakan metode bercerita meningkat menjadi 41,8\%. Hal ini menunjukkan bahwa penerapan metode bercerita berpengaruh positif terhadap kemampuan menyimak pada anak usia 5-6 tahun di TK Mutiara Kampung Godang.

\section{Gambaran Umum Kemampuan Menyimak Pada Anak Usia 5-6 Tahun di TK Mutiara Kampung Godang, Sebelum Penerapan Metode Bercerita (Pretest)}

Berdasarkan hasil pretest tersebut maka dapat dilihat bahwa kemampuan menyimak anak usia 5-6 tahun di TK Mutiara Kampung Godang dikategorikan rendah. Kegiatan pretest dilaksanakan 1 kali yaitu pada tanggal 23 Juli 2018. Pelaksanaan pretest bertujuan untuk mengetahui gambaran kemampuan menyimak anak sebelum diberikan metode bercerita, dapat dilihat pada tabel berikut. 
Tabel Kemampuan Menyimak Sebelum Diberikan Metode Bercerita

\begin{tabular}{|c|c|c|c|c|c|}
\hline No & Indikator & $\begin{array}{c}\text { Skor } \\
\text { Faktual }\end{array}$ & $\begin{array}{l}\text { Skor } \\
\text { Ideal }\end{array}$ & $\%$ & Kriteria \\
\hline 1 & $\begin{array}{l}\text { Menyebutkan berbagai } \\
\text { bunyi/ suara tertentu }\end{array}$ & 32 & 60 & 53,33 & MB \\
\hline 2 & Melihat ke arah pembaca & 32 & 60 & 53,33 & MB \\
\hline 3 & $\begin{array}{l}\text { Mimik wajah terlihat } \\
\text { senang mendengarkan dan } \\
\text { sesuai dengan apa yang } \\
\text { didengar }\end{array}$ & 26 & 60 & 43,33 & BB \\
\hline 4 & $\begin{array}{l}\text { Antusias mendengar cerita } \\
\text { dan berusaha mengikuti } \\
\text { cerita sampai selesai }\end{array}$ & 32 & 60 & 53,33 & MB \\
\hline 5 & $\begin{array}{l}\text { Menyimak perkataan orang } \\
\text { lain }\end{array}$ & 28 & 60 & 46,67 & MB \\
\hline 6 & $\begin{array}{l}\text { Mendengarkan saat guru } \\
\text { berbicara/ bercerita }\end{array}$ & 29 & 60 & 48,33 & $\mathrm{MB}$ \\
\hline 7 & $\begin{array}{l}\text { Memahami cerita yang } \\
\text { dibacakan }\end{array}$ & 24 & 60 & 40 & BB \\
\hline 8 & $\begin{array}{l}\text { Merespon pada saat cerita } \\
\text { sedang berlangsung dan } \\
\text { bertanya }\end{array}$ & 25 & 60 & 41,67 & MB \\
\hline 9 & Menyebutkan judul cerita & 19 & 60 & 31,67 & $\mathrm{BB}$ \\
\hline 10 & $\begin{array}{l}\text { Menyebutkan tokoh-tokoh } \\
\text { dalam cerita }\end{array}$ & 23 & 60 & 38,33 & BB \\
\hline 11 & $\begin{array}{l}\text { Menyebutkan sifat-sifat } \\
\text { tokoh yang ada pada cerita } \\
\text { yang di dengar }\end{array}$ & 26 & 60 & 43,33 & $\mathrm{MB}$ \\
\hline 12 & $\begin{array}{l}\text { Mengulang kalimat } \\
\text { sederhana }\end{array}$ & 27 & 60 & 45 & $\mathrm{MB}$ \\
\hline 13 & $\begin{array}{l}\text { Menceritakan kembali } \\
\text { cerita/ dongeng yang pernah } \\
\text { didengar }\end{array}$ & 23 & 60 & 38,33 & BB \\
\hline 14 & $\begin{array}{l}\text { Menjawab pertanyaan } \\
\text { dengan tepat sesuai dengan } \\
\text { cerita }\end{array}$ & 23 & 60 & 38,33 & BB \\
\hline & Jumlah & 369 & 840 & 615 & \\
\hline & Rata-rata & & & 43,92 & $\mathrm{MB}$ \\
\hline
\end{tabular}

Berdasarkan tabel di atas maka dapat diketahui bahwa pada skor akhir tertinggi terdapat pada indikator yaitu menyebutkan berbagai bunyi/ suara tertentu dengan skor akhir 32 persentase 53,33\% yang berada pada kriteria MB, melihat ke arah pembaca dengan skor akhir 32 persentase $53,33 \%$ yang berada pada kriteria MB, antusias mendengar cerita dan berusaha mengikuti cerita sampai selesai dengan skor akhir akhir 32 persentase 53,33\% yang berada pada kriteria MB. Skor akhir terendah terdapat pada indikator ke sembilan yaitu menyebutkan judul cerita dengan skor akhir 19 persentase $31,67 \%$ yang berada pada kriteria MB. 
Untuk mengetahui gambaran kemampuan menyimak anak sebelum diberikan perlakuan (treatment) menggunakan metode bercerita, dapat dilihat pada tabel 4.4

Tabel Kemampuan Menyimak Sebelum Perlakuan (Pretest)

\begin{tabular}{|c|l|c|c|c|}
\hline No & Kategori & Rentang Skor & F & \% \\
\hline 1 & BSB & $76-100 \%$ & 0 & $0 \%$ \\
\hline 2 & BSH & $56-75 \%$ & 0 & $0 \%$ \\
\hline 3 & MB & $41-55 \%$ & 13 & $87 \%$ \\
\hline 4 & BB & $<40 \%$ & 2 & $13 \%$ \\
\hline Jumlah & 15 & $100 \%$ \\
\hline
\end{tabular}

Berdasarkan tabel di atas maka dapat diketahui bahwa kemampuan menyimak anak sebelum menggunakan metode bercerita diperoleh data anak yang berada pada kategori BSB sebanyak 0 orang dengan persentase $0 \%$, anak yang berada pada kategori BSH sebanyak 0 orang dengan persentase $0 \%$, anak yang berada pada kategori MB sebanyak 13 orang dengan persentase $87 \%$ dan anak yang berada pada kategori BB sebanyak 2 orang dengan persentase $13 \%$. Untuk lebih jelasnya dapat dilihat pada grafik berikut ini :

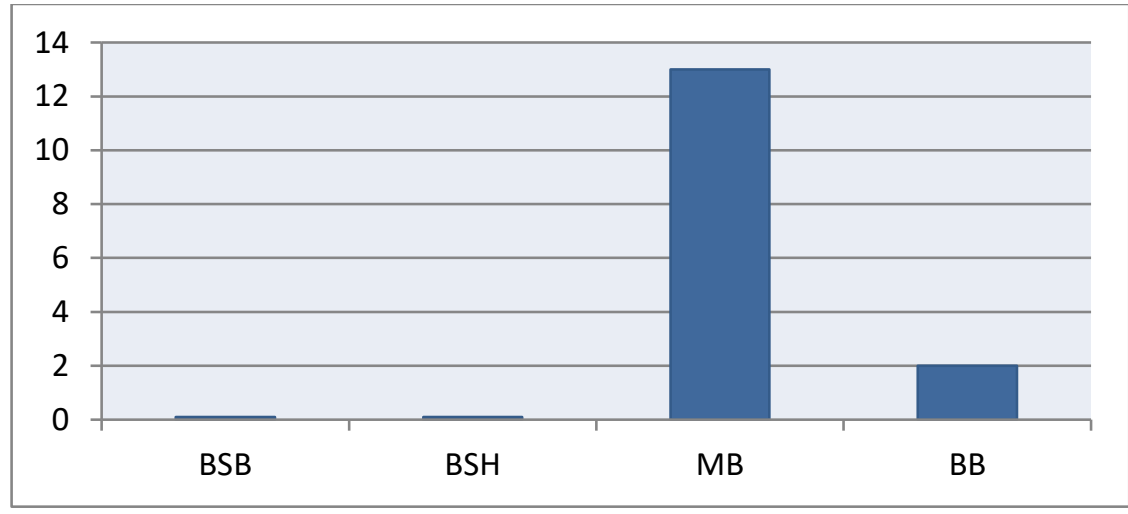

Gambar Diagram Kemampuan Menyimak Sebelum Perlakuan (Pretest)

\section{Gambaran Umum Kemampuan Menyimak Pada Anak Usia 5-6 Tahun di TK Mutiara Kampung Godang, Sebelum Penerapan Metode Bercerita (Posttest)}

Penelitian selanjutnya peneliti memberikan treatment dengan menggunakan metode bercerita untuk mengembangkan kemampuan menyimak anak yang dilakukan mulai tanggal 25 Juli - 30 Juli 2018. Pelaksanaan posttest bertujuan untuk mengetahui gambaran kemampuan menyimak anak setelah diberikan perlakuan (treatment) menggunakan metode bercerita, dapat dilihat pada tabel berikut.

Tabel Kemampuan Menyimak Sesudah Diberikan Metode Bercerita

\begin{tabular}{|l|l|l|l|l|l|}
\hline No & Indikator & $\begin{array}{l}\text { Skor } \\
\text { Faktual }\end{array}$ & $\begin{array}{l}\text { Skor } \\
\text { Ideal }\end{array}$ & $\%$ & Kriteria \\
\hline 1 & $\begin{array}{l}\text { Menyebutkan berbagai } \\
\text { bunyi/ suara tertentu }\end{array}$ & 55 & 60 & 91,67 & BSB \\
\hline 2 & Melihat ke arah pembaca & 53 & 60 & 88,33 & BSB \\
\hline 3 & $\begin{array}{l}\text { Mimik wajah terlihat } \\
\text { senang mendengarkan } \\
\text { dan sesuai dengan apa } \\
\text { yang didengar }\end{array}$ & 49 & 60 & 81,67 & BSB \\
\hline
\end{tabular}




\begin{tabular}{|c|c|c|c|c|c|}
\hline No & Indikator & $\begin{array}{l}\text { Skor } \\
\text { Faktual }\end{array}$ & $\begin{array}{l}\text { Skor } \\
\text { Ideal }\end{array}$ & $\%$ & Kriteria \\
\hline 4 & $\begin{array}{l}\text { Antusias mendengar } \\
\text { cerita dan berusaha } \\
\text { mengikuti cerita sampai } \\
\text { selesai }\end{array}$ & 45 & 60 & 75 & $\mathrm{BSH}$ \\
\hline 5 & $\begin{array}{l}\text { Menyimak perkataan } \\
\text { orang lain }\end{array}$ & 48 & 60 & 80 & BSB \\
\hline 6 & $\begin{array}{l}\text { Mendengarkan saat guru } \\
\text { berbicara/ bercerita }\end{array}$ & 47 & 60 & 78,33 & BSB \\
\hline 7 & $\begin{array}{l}\text { Memahami cerita yang } \\
\text { dibacakan }\end{array}$ & 41 & 60 & 68,33 & $\mathrm{BSH}$ \\
\hline 8 & $\begin{array}{l}\text { Merespon pada saat } \\
\text { cerita sedang } \\
\text { berlangsung dan } \\
\text { bertanya }\end{array}$ & 45 & 60 & 75 & BSH \\
\hline 9 & $\begin{array}{l}\text { Menyebutkan judul } \\
\text { cerita }\end{array}$ & 41 & 60 & 68,33 & $\mathrm{BSH}$ \\
\hline 10 & $\begin{array}{l}\text { Menyebutkan tokoh- } \\
\text { tokoh dalam cerita }\end{array}$ & 39 & 60 & 65 & $\mathrm{BSH}$ \\
\hline 11 & $\begin{array}{l}\text { Menyebutkan sifat-sifat } \\
\text { tokoh yang ada pada } \\
\text { cerita yang di dengar }\end{array}$ & 44 & 60 & 73,33 & $\mathrm{BSH}$ \\
\hline 12 & $\begin{array}{l}\text { Mengulang kalimat } \\
\text { sederhana }\end{array}$ & 40 & 60 & 66,67 & $\mathrm{BSH}$ \\
\hline 13 & $\begin{array}{l}\text { Menceritakan kembali } \\
\text { cerita/ dongeng yang } \\
\text { pernah didengar }\end{array}$ & 38 & 60 & 63,33 & $\mathrm{BSH}$ \\
\hline 14 & $\begin{array}{l}\text { Menjawab pertanyaan } \\
\text { dengan tepat sesuai } \\
\text { dengan cerita }\end{array}$ & 42 & 60 & 70,33 & $\mathrm{BSH}$ \\
\hline & Jumlah & 627 & 840 & 1045 & \\
\hline & Rata-rata & & & 74,64 & $\mathrm{BSH}$ \\
\hline
\end{tabular}

Berdasarkan tabel di atas maka dapat diketahui bahwa pada skor akhir tertinggi terdapat pada indikator ke satu yaitu menyebutkan berbagai bunyi/ suara tertentu dengan skor akhir akhir 55 persentase $91,67 \%$ yang berada pada kriteria BSB. Skor akhir terendah terdapat pada indikator ke tiga belas yaitu menceritakan kembali cerita/ dongeng yang pernah didengar dengan skor akhir 38 persentase 63,33\% yang berada pada kriteria BSH.

Untuk mengetahui gambaran kemampuan menyimak anak sesudah diberikan perlakuan (treatment) menggunakan metode bercerita, dapat dilihat pada tabel.

Tabel Kemampuan Menyimak Sesudah Perlakuan (Posttest)

\begin{tabular}{|c|l|c|c|c|}
\hline No & Kategori & Rentang Skor & F & \% \\
\hline 1 & BSB & $76-100 \%$ & 7 & $47 \%$ \\
\hline 2 & BSH & $56-75 \%$ & 8 & $53 \%$ \\
\hline 3 & MB & $41-55 \%$ & 0 & $0 \%$ \\
\hline 4 & BB & $<40 \%$ & 0 & $0 \%$ \\
\hline \multicolumn{2}{|l}{ Jumlah } & 15 & $100 \%$ \\
\hline
\end{tabular}


Berdasarkan tabel di atas maka dapat diketahui bahwa kemampuan menyimak anak sesudah menggunakan metode bercerita diperoleh data anak yang berada pada kategori BSB sebanyak 7 orang dengan persentase 47\%, anak yang berada pada kategori BSH sebanyak 8 orang dengan persentase $53 \%$, anak yang berada pada kategori MB sebanyak 0 orang dengan persentase $0 \%$ dan anak yang berada pada kategori BB sebanyak 0 orang dengan persentase $0 \%$. Untuk lebih jelasnya dapat dilihat pada grafik berikut ini :

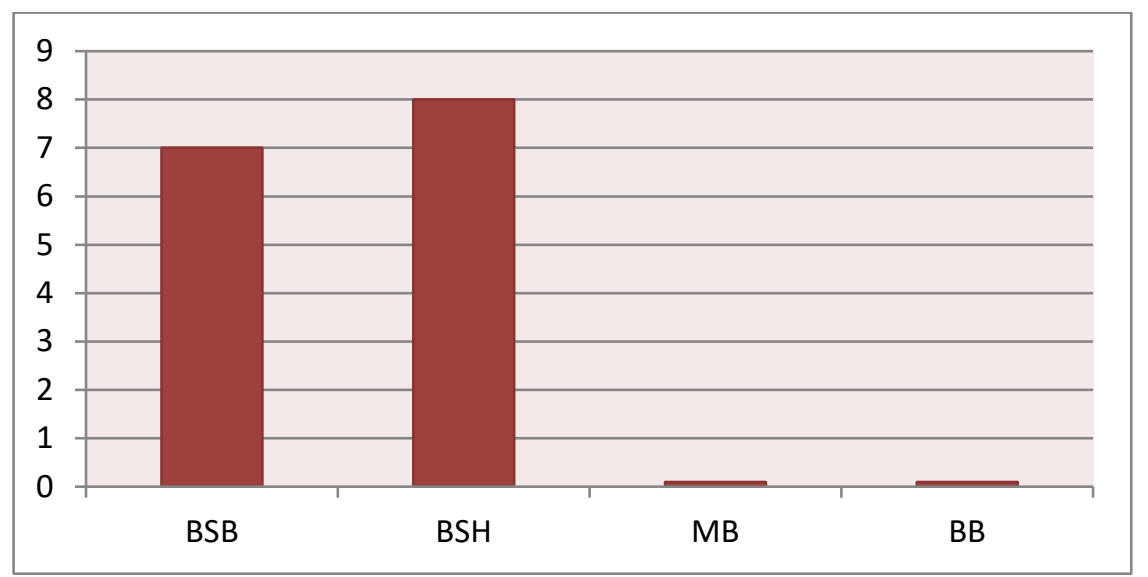

Gambar Diagram Kemampuan Menyimak Sesudah Perlakuan (Posttest)

Penelitian ini dilakukan menggunakan one group pretest posttest design yaitu melihat hasil pretest dan posttest. Adapun hasil pretest dan posttest, dapat dilihat pada tabel

Tabel Rekapitulasi Kemampuan Menyimak Sebelum dan Sesudah Diberikan Metode Bercerita di TK Mutiara Kampung Godang

\begin{tabular}{|c|l|c|c|c|c|c|}
\hline \multirow{2}{*}{ No } & \multirow{2}{*}{ Kategori } & \multirow{2}{*}{ Rentang Skor } & \multicolumn{2}{|c|}{ Sebelum } & \multicolumn{2}{c|}{ Sesudah } \\
\cline { 4 - 7 } & & & $\mathbf{F}$ & $\mathbf{\%}$ & $\mathbf{F}$ & $\mathbf{\%}$ \\
\hline 1 & BSB & $76-100 \%$ & 0 & $0 \%$ & 7 & $47 \%$ \\
\hline 2 & BSH & $56-75 \%$ & 0 & $0 \%$ & 8 & $53 \%$ \\
\hline 3 & MB & $41-55 \%$ & 13 & $87 \%$ & 0 & $0 \%$ \\
\hline 4 & BB & $<40 \%$ & 2 & $13 \%$ & 0 & $0 \%$ \\
\hline
\end{tabular}

Berdasarkan tabel di atas maka dapat diketahui bahwa perbandingan sebelum dan sesudah perlakuan (treatment) diatas dapat diketahui bahwa seluruh anak yang telah diberikan metode bercerita mengalami peningkatan kemampuan menyimak yaitu dilihat dari anak yang awalnya berada pada kategori BSB sebanyak 0 orang dengan persentase $0 \%$, anak yang berada pada kategori $\mathrm{BSH}$ sebanyak 0 orang dengan persentase $0 \%$, anak yang berada pada kategori MB sebanyak 13 orang dengan persentase $87 \%$ dan anak yang berada pada kategori BB sebanyak 2 orang dengan persentase $13 \%$. Kemudian terjadi peningkatan menjadi anak yang berada pada kategori BSB sebanyak 7 orang dengan persentase $47 \%$, anak yang berada pada kategori BSH sebanyak 8 orang dengan persentase $53 \%$, anak yang berada pada kategori MB sebanyak 0 orang dengan persentase $0 \%$ dan anak yang berada pada kategori BB sebanyak 0 orang dengan persentase $0 \%$. Untuk lebih jelasnya dapat dilihat pada grafik berikut ini : 


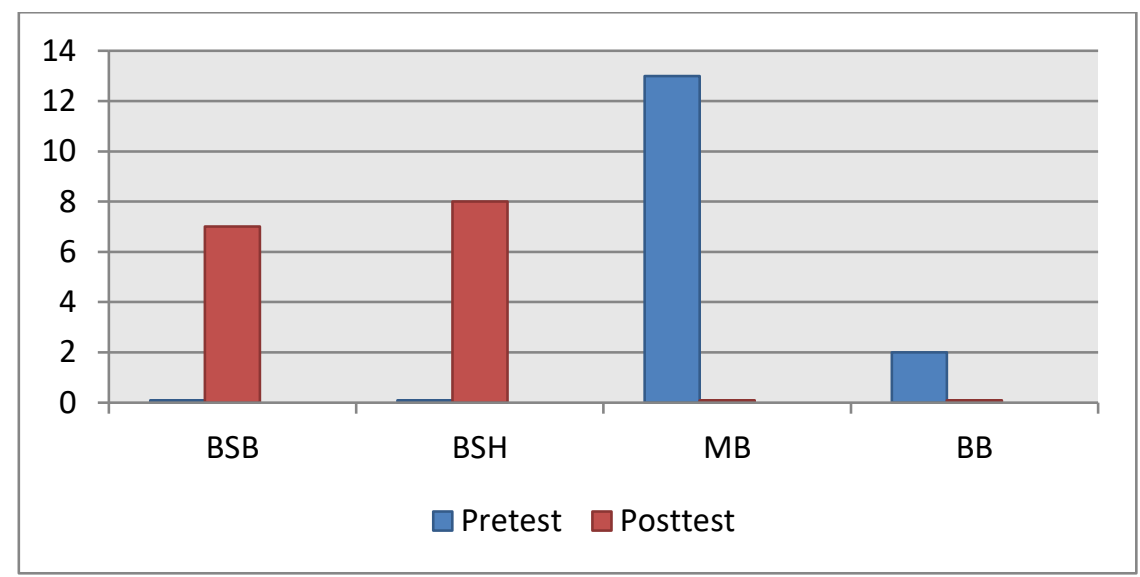

\section{Gambar Diagram Kemampuan Menyimak Sebelum Perlakuan (Pretest) dan Sesudah Perlakuan (Posttest)}

\section{Pengaruh Penerapan Metode Bercerita Terhadap Kemampuan Menyimak Pada Anak Usia 5-6 Tahun di TK Mutiara Kampung Godang}

Untuk mengetahun seberapa besar efektif pengaruh metode bercerita terhadap kemampuan menyimak di TK Mutiara Kampung Godang. Data di uji secara statistik adalah data N-Gain (gain ternomalisasi) yang diperkenalkan oleh Hake. N-Gain digunakan untuk mengukur selisih antara nilai pretest dan posttest dan untuk menunjukkan kategori peningkatan kemampuan menyimak setelah penerapan metode maka dilakukan uji gain ternomalisasi. Adapun hasil uji gain sebagai berikut:

$$
\begin{aligned}
G & =\frac{\text { Skor Akhir }(\text { Posttest })-\text { Skor Awal (Pretest) }}{\text { Skor Maximal }- \text { Skor Awal (Pretest) }} \times 100 \% \\
G & =\frac{627-369}{840-369} \times 100 \% \\
G & =\frac{258}{471} \times 100 \% \\
G & =0,5477 \times 100 \% \\
G & =54,77 \%
\end{aligned}
$$

Berdasarkan hasil perhitungan di atas dapat disimpulkan bahwa metode bercerita dapat berpengaruh terhadap kemampuan menyimak anak usia 5-6 tahun di TK Mutiara Kampung Godang sebesar 54,77\% terdapat pada kategori sedang. Untuk melihat klasifikasi nilai N-Gain ternormalisasi dapat dilihat pada tabel berikut:

Tabel 4.8

Kategori Gain Ternormalisasi

\begin{tabular}{|c|c|}
\hline Gain Ternormalisasi & Kriterian Peningkatan \\
\hline$G<30 \%$ & Rendah \\
\hline $30 \% \leq G \leq 70 \%$ & Sedang \\
\hline$G \geq 70 \%$ & Tinggi \\
\hline
\end{tabular}

\section{Pengujian Hipotesis}

Pengujian hipotesis dalam penelitian ini menggunakan uji t atau t-test untuk melihat perbedaan sebelum dan sesudah perlakuan serta untuk melihat seberapa besar pengaruh metode bercerita terhadap kemampuan menyimak pada anak usai 5-6 tahun. Berdasarkan hasil uji normalitas dan uji homogenitas menunjukkan bahwa data yang 
diperoleh berdistribusi normal memiliki varians data yang bersifat homogen atau memiliki varians yang sama besar. Hasil perhitungan uji hipotesis dapat dilihat pada tabel.

Tabel Uji Hipotesis Posttest Kemampuan Menyimak

\begin{tabular}{|c|c|}
\hline Statistik & Posttest Kemampuan Menyimak \\
\hline $\mathrm{N}$ & 14 \\
\hline $\mathrm{d}$ & 17,2 \\
\hline$t_{\text {hitung }}$ & 21,187 \\
\hline$t_{\text {tabel }}$ & 2,145 \\
\hline
\end{tabular}

Pada taraf nyata $(\alpha)=5 \%$ diperoleh nilai $t_{\text {tabel }}=2,145$. Jika dibandingkan dengan $t_{\text {hitung }}=21,187$, diperoleh $t_{\text {hitung }}>t_{\text {tabel }}$ maka dapat disimpulkan hipotesis nihil $\left(\mathrm{H}_{0}\right)$ ditolak dan hipotesis alternatif $\left(\mathrm{H}_{\mathrm{a}}\right)$ diterima. Artinya adanya pengaruh yang signifikan antara metode bercerita terhadap kemampuan menyimak pada anak usia 5-6 tahun di TK Mutiara Kampung Godang. Perhitungan secara lengkap dapat dilihat pada lampiran 17 halaman 135.

Analisis data juga dilaksanakan menggunakan SPSS bertujuan untuk memperkuat analisis secara manual. Pengujian hipotesis menggunakan program SPSS 16.0. Hasil output secara lengkap dapat dilihat pada lampiran 21 halaman 140. Hasil perhitungan uji hipotesis menggunakan SPSS dapat dilihat pada tabel 4.13

Tabel Uji Hipotesis Kemampuan Menyimak

Paired Samples Test

\begin{tabular}{|c|c|c|c|c|c|c|c|c|c|}
\hline & & Paired I & Differe & & & & & & \\
\hline & & & & & $\begin{array}{l}95 \% \\
\text { Confide } \\
\text { Interval } \\
\text { Differe }\end{array}$ & $\begin{array}{l}\text { ence } \\
\text { lof the } \\
\text { nce }\end{array}$ & & & \\
\hline & & & & & Lower & Upper & & & \\
\hline $\begin{array}{l}\text { Pair } \\
1\end{array}$ & $\begin{array}{l}\text { METODE } \\
\text { BERCERITA - } \\
\text { KEMAMPUAN } \\
\text { MENYIMAK }\end{array}$ & 17.200 & 3.144 & .812 & $-\overline{18.941}$ & - 15.459 & 21.187 & 14 & \\
\hline
\end{tabular}

Berdasarkan tabel 4.13 di atas, pada Independent Sampel Test (uji hipotesis) menunjukkan bahwa nilai probabilitas (signifikansi) adalah 0.000 , karena nilai probabilitas $0.000<0.05$ maka dapat disimpulkan $\mathrm{H}_{0}$ tolak dan $\mathrm{H}_{\mathrm{a}}$ diterima. Hal ini membuktikan bahwa terdapat pengaruh penerapan metode bercerita terhadap kemampuan menyimak pada anak usia 5-6 tahun di TK Mutiara Kampung Godang.

\section{Pembahasan Hasil Analisis Data}

Setelah dilakukan pengujian diperoleh bahwa terdapat perbedaan antara hasil kemampuan menyimak dengan menggunakan metode bercerita dan dengan menyimak tanpa menggunakan metode bercerita. Hasil kemampuan menyimak dengan metode bercerita lebih tinggi atau lebih baik dibandingkan dengan hasil menyimak dengan pembelajaran tanpa metode mendongeng. Berdasarkan analisa data dari hasil pretest (sebelum perlakuan) menggunakan metode bercerita diperoleh jumlah nilai sebesar 369 dengan rata-rata $24,6 \%$. 
Namun, setelah diberi perlakuan (treatment) dengan menerapkan metode bercerita, anak memperlihatkan antusias ketika mendengarkan cerita cerita setiap cerita yang diceritakan oleh peneliti. Setelah anak mendengarkan cerita, dilakukan penilaian terhadap kemampuan menyimak. Berdasarkan analisa data dari hasil posttest (sesudah perlakuan) menggunakan metode bercerita terjadi peningkatan nilai yang didapat dilihat dari hasil posttest (sesudah perlakuan) diperoleh nilai 627 dengan rata-rata 41,8\%. Selain itu, berdasarkan hasil perhitungan uji hipotesis menunjukkan bahwa nilai probabilitas (signifikansi) data posttest sebesar 0,000. Karena nilai signifikansi $0.000<0.05$ maka $\mathrm{H}_{0}$ ditolak. Hal ini membuktikan bahwa terdapat pengaruh pada kemampuan menyimak dengan menggunakan metode bercerita. Maka dari itu, metode bercerita dapat dijadikan acuan oleh guru dalam proses pembelajaran khususnya dalam kegiatan menyimak.

\section{DAFTAR PUSTAKA}

Arikunto, suharsimi. (2006). Prosedur Penelitian Suatu Pendekatan Praktik. Jakarta: PT Rineka Cipta.

Asriana. (2014). Pengaruh Metode Gerak dan Lagu Terhadap Kemampuan Menyimak Anak Usia 5-6 Tahun di TK Education 21 Kulim Pekanbaru. Universitas Riau, Pekanbaru: Skripsi Tidak Dipublikasikan.

Bimo. (2010). Makalah Ringkas. [Online]. Tersedia dalam: https://kakbimo.wordpress.com/makalah-ringkas/ [diakses 25 Desember 2017].

Dhieni, Nurbiana dkk. (2007). Metode Pengembangan Bahasa. Jakarta: Universitas Terbuka.

Upheksa, Ellen. (2013). Peningkatan Keterampilan Menyimak Melalui Metode Bercerita Pada Anak Kelompok B2 TK Islam Darul Muttaqin Kecamatan Purworejo Kabupaten Purworejo. dalam Journal Universitas Negeri Yogyakarta. Desember, 2013. Tersedia dalam: http://eprints.uny.ac.id/14680/1/SKRIPSI.pdf [diakses 26 Februari 2018].

Fauziddin, Mohammad. (2014). Pembelajaran Paud. Bandung: PT Remaja Rosdakarya. Fitriyani, Nur. (2017). Peningkatan Kemampuan Berbicara Anak Melalui Media Cerita Bergambar Pada Anak Kelompok B TK Ayu Smart Kids Batu Belah. Universitas Pahlawan Tuanku Tambusai, Bangkinang: Skripsi Tidak Dipublikasikan.

Gunarti, dkk. (2010). Metode Pengembangan Perilaku dan Kemampuan Dasar Anak Usia Dini. Jakarta: Universitas Terbuka.

Intan, K. S. (2013). Pengaruh Penggunaan Metode Brain Gym Terhadap Peningkatan Kemampuan Menyimak Anak Usia 4-5 Tahun di TK Istan Balita Surabaya. dalam Journal Universitas Negeri Surabaya. Vol. 2, No. 3, September 2013. tersedia dalam: $\quad$ http://ejournal.unesa.ac.id/index.php/paud-teratai/article/view/3611 [diakses 26 Februari 2018].

Isjoni. (2011). Model Pembelajaran Anak Usia Dini. Bandung: Alfabeta.

Melly. (2015). Ciri-ciri Umum dan Tugas Perkembangan Anak Usia Dini. [Online]. Tersedia dalam: https://mellyhandayanicyrus.wordpress.com/2015/05/16/ciri-ciriumum-dan-tugas-perkembangan-anak-usia-dini-2/ [diakses 26 Februari 2018].

Menteri Pendidikan dan Kebudayaan Republik Indonesia. 2014. Peraturan Menteri Pendidikan dan Kebudayaan Republik Indonesia Nomor 137 Tahun 2014 Tentang Standar Nasional Pendidikan Anak Usia Dini. Menteri Pendidikan dan Kebudayaan Republik Indonesia : Jakarta.

Menteri Pendidikan dan Kebudayaan Republik Indonesia. 2014. Peraturan Menteri Pendidikan dan Kebudayaan Republik Indonesia Nomor 146 Tahun 2014 Tentang Kurikulum 2013 Pendidikan Anak Usia Dini. Menteri Pendidikan dan Kebudayaan Republik Indonesia : Jakarta. 
Moeslichatoen. (2004). Metode Pengajaran di Taman Kanak-Kanak. Jakarta: Rineka Cipta.

Naibaho, Santha. (2017). Pengaruh Kegiatan Montase terhadap Kemampuan Motorik Halus Anak Usia 5-6 Tahun di TK Tunas Melati Kandis. Universitas Riau, Pekanbaru: Skripsi Tidak Dipublikasikan.

Rachmawati, Y.\& Kurniati. (2010). Strategi Pengembangan Kreatifitas Pada Anak Usia Taman Kanak-kanak. Jakarta: Kencana.

Rahmat, Abdul. (2016). Pengaruh Metode Bercerita Terhadap Kemampuan Menyimak Anak Usia 4-5 Tahun di TK Negeri Pembina Ki Hadjar Dewantoro Kecamatan Kota Selatan Kota Gorontalo. dalam Journal Universitas Negeri Surabaya. Vol. 5, No. 1, Juni 2016. Tersedia dalam: https://journal.unnes.ac.id/sju/index.php/jnfc/article/view/9728 [diakses 26 Februari 2018].

Said, A \& Andi. (2015). 95 Strategi Mengajar Multiple Intelligences. Jakarta: Kencana. Siregar, S. (2014). Statistik Parametrik untuk Penelitian Kuntitatif. Jakarta: Bumi Aksara. Siregar, S. (2014). Metode Penelitian Pendidikan Pendekatan Kuantitatif Kualitatif dan $R \& D$. Bandung: Alfabeta.

Siregar, S. (2017). Statistika untuk Penelitian. Bandung: Alfabeta.

Sujiono, Yuliani Nurani. (2009). Konsep Dasar Pendidikan Anak Usia Dini. Jakarta: PT Indeks.

Tarigan, Henry Guntur. (2008). Menyimak Sebagai Keterampilan Bahasa. Bandung: Angkasa.

Trianto. (2011). Model Pembelajaran Terpadu. Jakarta: Bumi Aksara. 